\title{
Effect of Monetary Policy on Economic Growth in Nigeria
}

\author{
Onwuteaka, Ifeoma Cecilia' ${ }^{1}$ Ph.D, Okoye, P. V. C ${ }^{2}$ Ph.D, Molokwu, Ifeoma Mirian ${ }^{3}$ \\ 1Departent of Economics, Anambra State University, Anambra State, Nigeria \\ 2Department of Accountancy, Nnamdi Azikiwe University (NAU), Awka, Nigeria \\ ${ }^{3}$ Department of Accountancy, Anambra State Polytechnic, Mgbakwu, Nigeria
}

\begin{abstract}
How to cite this paper: Onwuteaka, Ifeoma Cecilia | Okoye, P. V. C | Molokwu, Ifeoma Mirian "Effect of Monetary Policy on Economic Growth in Nigeria" Published in International Journal of Trend in Scientific Research and Development (ijtsrd), ISSN: 24566470, Volume-3 | Issue-3 , April 2019, pp.590-597, URL: http://www.ijtsrd.co $\mathrm{m} /$ papers/ijtsrd229

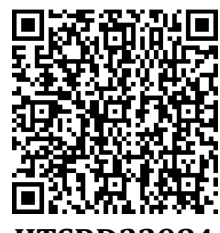
IITSRD22984
\end{abstract} 84.pdf

Copyright (C) 2019 by author(s) and International Journal of Trend in Scientific Research and Development Journal. This is an Open Access article distributed under the terms of the Creative Commons Attribution License (CC BY 4.0) (http://creativeco mmons.org/license s/by/4.
ABSTRACT

The chequered history of the Nigeria monetary policy has created a visible asymmetry in the two known monetary regimes (before and after SAP) in the country. Years after the Structural Adjustment Programme (SAP), the Nigeria economy grew to become the strongest economy in Africa and suddenly plunging into recession, a situation that have adversely affected the growth and development of the economy by ways of rising unemployment rate, soaring poverty and swollen external debt, thus suggesting that the failure of the monetary policy in curbing price instability has caused growth instability as Nigeria's record of growth and development has become very poor. This study therefore examines the effect of monetary policy on economic growth in Nigeria using secondary data covering the period of 1980-2017 that were sourced from the Central Bank of Nigeria statistical bulletin. The model's estimates were estimated via multiple econometric model of the ordinary least square to ascertain the effect of money supply, credit in the economy, interest rate on credit, infrastructure, inflationary rate, external debts, price index on growth in Nigeria. The results show that money supply, interest rate on credit, infrastructure and external debt were statistically significant in explaining its impacts on economic growth while other variables used in the study were all found to be statistically insignificant in explaining the growth rate of the Nigerian economy. The study recommends among others that for effective operation of the monetary policy measures in the Nigerian economy, the Central Bank of Nigeria should be granted full autonomy on its monetary policy functions. Partial autonomy should be replaced with full autonomy for the central banks in the developing economies at large which is invariably subjected to government interference and its politics.

Keywords: Monetary Policy, Economic Growth, Money Supply, Infrastructure, Inflationary Rate, External Debts, Price Index

\section{INTRODUCTION}

A policy could be described as a rule, strategy, plan, guiding principle, procedure or guideline for developing and sustaining a course of action on continuing and consistent bases. In economic parlance therefore, monetary policy should be seen as guiding principle or procedure for developing, controlling and sustaining monetary variables of an economy that induce growth. Extant literature holds that monetary policy is a key factor of macroeconomic management in opened economy to stimulate economic stability and to promote economic development through its impact on economic variables. It is generally believe that monetary policy influences macroeconomic variables which include employment creation, price stability, gross domestic product growth and equilibrium in the balance of payment in developing country (Srithilat \& Sun, 2017; Anowor \& Okorie, 2016; Precious, 2014). As a technique of economic management, monetary policy is geared toward achieving the economic growth and economic performance of an economy. The policy has to do with the regulation of money supply, inflationary rate, credit supply, interest rate on credit, external debts and price index. As cited by Nwoko,
Ihemeje and Anumadu (2016), monetary policy refers to the combination of measures designed to regulate the value, supply and cost of money in an economy in consonance with the level of economic activities. It can also be described as the art of controlling the direction and movement of monetary and credit facilities in pursuance of stable price and economic growth in the economy (CBN 1992). It is the responsibility of the monetary authority of a country to design and implement the monetary policy. In Nigeria, the Central Bank of Nigeria (CBN) is charged with this responsibility. The CBN was establishment in 1959 and since its inception; the Central Bank of Nigeria (CBN) has continued to play the traditional role expected of an apex bank by regulating the stock of money supply, inflationary rate, credit supply, interest rate on credit, external debts and price index. This role is anchored on the use of monetary policy that is usually targeted towards the achievement of full-employment equilibrium, rapid economic growth, price stability, and external balance. Over the years, the major goals of monetary policy have often been the two later objectives. Thus, inflation targeting and exchange rate policy 
have dominated CBN's monetary policy focus based on assumption that these are essential tools of achieving macroeconomic stability (Fasanya, Onakoya \& Agboluaje, 2013; Ajayi, 1999).

Two major periods have characterized monetary policy in Nigeria: the fixed regime and market mechanism regime. These regimes took place in the post-and pre-1986 periods. Before 1986, direct monetary control was used in achieving price stability in Nigeria, while the emphasis shifted to market mechanisms after the 1986 market liberalization (Ufoeze, Odimgbe, Ezeabalisi \& Alajekwu, 2018; Uchendu, 2009). Prior to 1986, direct monetary instruments such as selective credit controls, administered interest and exchange rates, credit ceilings, cash reserve requirements and special deposits to combat inflation and maintain price stability were employed. The fixing of interest rates at relatively low levels was done mainly to promote investment and growth. Occasionally, special deposits were imposed to reduce the amount of excess reserves and credit creating capacity of the banks (Ufoeze, Odimgbe, Ezeabalisi \& Alajekwu, 2018; Uchendu, 2009; Okafor, 2009). According to Ufoeze, Odimgbe, Ezeabalisi \& Alajekwu (2018), in the above period, the monetary control framework seems to have failed to achieve the set monetary targets as their implementation became less effective with time. The rigidly controlled interest rate regime and the non-harmonization of fiscal and monetary policies may have contributed immensely to the adverse effect of constraining growth of the money and capital markets. On the other hand the market mechanism regime that spanned to date seems to have worsened the economic situation in the country thus leaving the populace in doubt on the credibility of the policy makers in the country. The chequered history of the Nigeria monetary policy has created a visible asymmetry in the two known monetary regimes in the country with Nigeria having the strongest economy in Africa and suddenly plunging into recession, a situation that have adversely affected the growth and development of the economy by way of rising unemployment rate, soaring poverty and swollen external debt, thus suggesting that the failure of the monetary policy in curbing price instability has caused growth instability as Nigeria's record of growth and development has been very poor. According to Adigwe, Echekoba \& Onyeagba (2015), despite the various monetary regimes that have been adopted by the Central Bank of Nigeria over the years, inflation still remains a major threat to Nigeria's economic growth. Nigeria has experienced high volatility in inflation rates. Since the early 1970 's, there has been more than three major episodes of high inflation in excess of 30 percent. The growth of money supply is correlated with this high inflation episode because money growth was often in excess of real economic growth. Again, the dualistic nature of financial and product market in Nigeria constitutes a fundamental constraint militating against the formulation and efficient implementation of monetary policy. The informal sector in Nigeria accounts for about 30 percent of the GDP, thus the existence of a large informal credit market and exchange rate market in Nigeria has many implications for the transmission mechanism of monetary policy. Furthermore, the payment system is a vital link between the financial and the real sector of the economy. The payment system in Nigeria is predominantly cash and the prominence of cash for transaction purposes increases the volume of money/currency in circulation which renders monetary control difficult. Nasko (2016) noted that the effective management of the monetary policy is a fundamental prerequisite in ensuring adequate liquidation in the banking system and sectoral credit allocation to the sensitive Sectors of the economy. This aptly means that Monetary Authority applies discretionary power to influence the money stock and interest rate to make money either more expensive or cheaper depending on the prevailing economic conditions and policy stance geared towards achieving price stability.

\section{Objectives of the Study}

The main objective of this study is to examine the effect of monetary policy on economic growth in Nigeria. The specific objectives of the study are to determine the effect of money supply, inflationary rate, credit to the private sector, interest rate on credit, infrastructural development, external debts and rice index on economic growth in Nigeria.

\section{Statement of Hypothesis}

Ho $_{1}$ : Money supply, inflationary rate, credit to the private sector, interest rate on credit, infrastructural development, external debts and rice index have no significant effect on economic growth in Nigeria

\section{Related Empirical Literature}

Ayodeji and Oluwole (2018) examined the impact of monetary policy on economic growth in Nigeria by developing a model that is able to investigate how monetary policy of the government has affected economic growth through the use of multi-variable regression analysis. Error Correction Model was introduced in order to have a parsimonious model. From the result, two variables (money supply and exchange rate) had a positive but fairly insignificant impact on economic growth. Measures of interest rate and liquidity ratio on the other hand, had a negative but highly significant impact on economic growth. Ufoeze, Odimgbe, Ezeabalisi and Alajekwu (2018) investigated the effect of monetary policy on economic growth in Nigeria by including the the natural log of the GDP as the dependent variables against the explanatory monetary policy variables: monetary policy rate, money supply, exchange rate, lending rate and investment for the marketcontrolled period covering 1986 to 2016. The study adopted an Ordinary Least Squared technique and also conducted the unit root and co-integration tests. The study showed that long run relationship exists among the variables. In addition, the core finding of this study showed that monetary policy rate, interest rate, and investment have insignificant positive effect on economic growth in Nigeria. Money supply however has significant positive effect on growth in Nigeria. Exchange rate has significant negative effect on GDP in Nigeria. Money supply and investment granger cause economic growth, while economic growth causes interest rate in Nigeria. On the overall, monetary policy explains $98 \%$ of the changes in economic growth in Nigeria. Srithilat and Sun (2017) examined the impact of monetary policy on the economic development by using annual time series data from 1989-2016. Error Correction Model was employed to analyze the association between variables. The finding shows that money supply, interest rate and inflation rate negatively affect the real GDP per capita in the long run and only the real exchange rate has a positive sign. The error correction model result indicates the existence of short run causality between money supply, real exchange rate and real GDP per capita.

Nwoko, Ihemeje \& Anumadu (2016) examined the extent to which the Central Bank of Nigeria Monetary Policies could 
effectively be used to promote economic growth, covering the period of 1990-2011. The influence of money supply, average price, interest rate and labour force were tested on Gross Domestic Product using the multiple regression models as the main statistical tool of analysis. Studies show that CBN Monetary Policy measures are effective in regulating both the monetary and real sector aggregates such as employment, prices, level of output and the rate of economic growth. Empirical findings from this study indicate that average price and labour force have significant influence on Gross Domestic Product while money supply was not significant. Interest rate was negative and statistically significant. Nasko (2016) examined the impact of monetary policy on economic growth in Nigeria using multiple regressions and time-series data covering the range of 1990 to 2010 were employed to analyze data on variables such as money supply, interest rate, financial deepening and gross domestic product. They were all found to have marginal impact on the economic growth of Nigeria. The study shows further, the aims and objectives of monetary policy, which includes price stability, maintenance of balance of payment equilibrium, full employment and economic growth. The study found marginal impact on growth due to change in monetary policy application. Ahmad, Afzal and Ghani (2016) examined the impact of monetary policy on economic growth in Pakistan using Autoregressive Distribution Lag (ARDL) Cointegration approach and an annual time-series data covering the range of 1973 to 2014 were applied to distinguish the robust among the variables with specification of short-run and long-run. Empirical findings mentioned long-run association occurs among variables, money supply and exchange rate, which positively influence economic growth. Inflation positively while insignificance and interest rate negatively affect economic growth. Adigwe, Echekoba \& Onyeagba (2015) examined the impact of monetary policy on the Nigerian economy using the regression technique of the Ordinary Least Square Method (OLS) and data covering a period 1980 and 2010. The result of the analysis shows that monetary policy represented by money supply exerts a positive impact on GDP growth but negative impact on the rate of inflation. Usman and Adejare (2014), examines the impact of monetary policy on industrial growth in Nigerian economy, multiple regressions were employed to analyze data on such variables, manufacturing output, Treasury Bills, Deposit \& leading and Rediscount Rate for Nigeria over the period 1970 to 2010 were all found have significant effects on the industrial Growth with the Adjusted R2 of 0.8156 (81.56\%). the study concluded that Rediscount Rate, and Deposit have significant positive effect on industrial output but Treasury Bills has the negative impact on industrial output. All the variables are statistically significant. Mbutor and Uba (2013) examined the impact of financial inclusion on monetary policy in Nigeria between 1980 and 2012. The result of the study supports the notion that growing financial inclusion would improve the effectiveness of monetary policy. However, the coefficient of the number of bank branches has the wrong sign and this is explained by the fact that, in opening branches, banks mainly pursue profits but not financial inclusion which is a policy objective, so that there are clusters of branches which are under-utilized while numerous locations which are considered not favourable for balance sheets are under-branched. Fasanya, Onakoya and Agboluaje (2013) examined the impact of monetary policy on economic growth in Nigeria using time-series data covering the range of 1975 to 2010.The effects of stochastic shocks of each of the endogenous variables are explored using Error Correction Model (ECM). The study showed that Long run relationship exists among the variables. Also, the core finding of this study shows that inflation rate, exchange rate and external reserve are significant monetary policy instruments that drive growth in Nigeria. Onyeiwu (2012) examined the impact of monetary policy on the Nigerian economy using a regression model of the Ordinary Least Squares Method (OLS) to analyse data between 1981 and 2008. The result of the analysis shows that monetary policy presented by money supply exerts a positive impact on GDP growth and Balance of Payment but negative impact on rate of inflation.

Charles-Anyaogu (2012), examined the performance of monetary policy on the manufacturing index performance in Nigeria. The data collected from the CBN 2010 bulletin were subjected to econometric test procedures such as unit root for stationarity of series, diagnostic test and granger causality to investigate the impact of some macroeconomic variables on the Manufacturing index in Nigeria while VEC and OLS estimation were used to study the models for significance, magnitude, direction and relationship. The study revealed that MS positively affect MANDEX by $0.5 \%$ while others played negative impact to the performance of the manufacturing sector over the years. Fasanya, Onakoya and Agboluaje (2013) examined the impact of monetary policy on economic growth in Nigeria. The study uses timeseries data covering the range of 1975 to 2010.The effects of stochastic shocks of each of the endogenous variables are explored using Error Correction Model (ECM). The study shows that Long run relationship exists among the variables. Also, the core finding of this study shows that inflation rate, exchange rate and external reserve are significant monetary policy instruments that drive growth in Nigeria. Onyeiwu (2012), examines the impact of monetary policy on the Nigerian economy. In doing this, the Ordinary Least Squares Method (OLS) is used to analyse data between 1981 and 2008. The result of the analysis shows that monetary policy presented by money supply exerts a positive impact on GDP growth and Balance of Payment but negative impact on rate of inflation. Chuku (2009), carried out a controlled experiment using a structural vector autoregression (SVAR) model to trace the effects of monetary policy shocks on output and prices in Nigeria. He made the assumption that the Central Bank cannot observe unexpected changes in output and prices within the same period. This places a recursive restriction on the disturbances of the SVAR. The study was conduct using three alternative policy instruments i.e. broad money (M2), Minimum Rediscount Rate (MRR) and the real effective exchange rate (REER). Overall, it was observed that monetary policy innovations carried out on the quantity-based nominal anchor (M2) has modest effects on output and prices with a very fast speed of adjustment. While, innovations on the price-based nominal anchors (MRR and REER) have neutral and fleeting effects on output. The study concludes that the manipulation of the quantity of money (M2) in the economy is the most influential instrument for monetary policy implementation. In the final analysis, monetary policy has been viewed as a technique of economic management to bring about sustainable economic growth and development. It has been the pursuit of nations and formal articulation of how money affects economic aggregates dates back the time of Adams Smith and later championed by the monetary economists. Since the expositions of the role of monetary policy in influencing macroeconomic objectives like economic growth, 
price stability, equilibrium in balance of payments and host of other objectives, monetary authorities are saddled the responsibility of using monetary policy to grow their economies. In Nigeria, monetary policy has been used since the Central bank of Nigeria was saddled the responsibility of formulating and implementing monetary policy by Central bank Act of 1958. This role has facilitated the emergence of active money market where treasury bills, a financial instrument used for open market operations and raising debt for government has grown in volume and value becoming a prominent earning asset for investors and source of balancing liquidity in the market (Anazor, 2015).

From the literature reviewed, linkage between monetary policy and economic growth has been a subject of intense scrutiny, but despite the various monetary regimes that have been adopted by the Central Bank of Nigeria over the years, adverse exchange rate volatility and inflation still remain a major threat to Nigeria's economic growth and stability. Nigeria has experienced high volatility in inflation and exchange rates (Anazor, 2015). The main thrust of this study is to evaluate the effectiveness of the CBN's monetary policy over the years by examining the effect of monetary policy on economic growth in Nigeria. The specific objectives of the study are to determine the effect of money supply, inflationary rate, credit to the private sector, interest rate on credit, infrastructural development, external debts and rice index on economic growth in Nigeria. This would go a long way in assessing the extent to which the monetary policies have impacted on the growth process of Nigeria using the major objectives of monetary policy as yardstick.

\section{METHODOLOGY}

\section{Model Specifications}

The model to be adopted will specifically be based on the following functional relationship:

$$
\mathrm{GDP}=\mathrm{F}(\mathrm{MS}, \mathrm{INF}, \mathrm{CRD}, \mathrm{INTC} \text {, INFRA, EXD, PIND) }
$$

From the model GDP is a function of money supply, inflationary rate, credit to the private sector, interest rate on credit, infrastructural development, external debts and price index. However, to hold firm the influence of the random variable, the equation is explicitly transformed into mathematical form as:

$$
\begin{aligned}
\mathrm{GDP}=\beta_{0}+ & \beta_{1} \mathrm{MS}+\beta_{2} \mathrm{INF}+\beta_{3} \mathrm{CRD}+\beta_{4} \mathrm{INTC}+\beta_{5} \mathrm{INFRA} \\
& +\beta_{6} \mathrm{EXD}+\beta_{7} \mathrm{PIND}
\end{aligned}
$$

Hence, the econometric form of the model is:

$$
\mathrm{GDP}=\beta_{0}+\beta_{1} \mathrm{MS}
$$

$+\beta_{2}$ INF $+\beta_{3} \mathrm{CRD}+\beta_{4} \mathrm{INTC}+\beta_{5} \mathrm{INFRA}+\beta_{6} \mathrm{EXD}+\beta_{7} \mathrm{PIND}+\mu_{\mathrm{i}}$

Where: GDP $=$ Gross Domestic Product

$\mathrm{MS}=$ money supply

$\mathrm{INF}=$ inflationary rate
$\mathrm{CRD}=$ credit to the private sector

INTC $=$ interest rate on credit

INFRA = infrastructural development

EXD = external debts

PIND $=$ price index

The parameter estimates are $\beta_{1}, \beta_{2}, \beta_{3}, \beta_{4}, \beta_{5}, \beta_{6}, \beta_{7}$ while $\beta_{0}$ is the parameter constant.

$\mu=$ error term

This research will examine the effect of monetary policy on economic growth and development in Nigeria. Since the data to be employed are time series data, an ordinary least square (OLS) method will be used to estimate the model parameters. In order to facilitate time series analysis, secondary data covering the period from 1980-2017 will be obtained from Central Bank of Nigeria (CBN) statistical bulletin of various issues.

The method adopted for evaluation of the model is the multiple linear regression method of ordinary least square (OLS). The techniques to be used in the analysis are:

1. Signs and magnitude of parameters: this is suggestion about the sign of the parameters and possibility of their sizes.

2. Coefficient of multiple determinations $\left(R^{2}\right)$ and adjusted $\left(\mathbf{R}^{2}\right)$ will be used to test for the goodness of fit. The value of $\mathrm{R}^{2}$ lies between 0 and 1 . The closer the $\mathrm{R}^{2}$ is to 1 , the better the goodness of fit whereas the closer the $\mathrm{R}^{2}$ is to 0 , the worse the goodness of fit.

3. t - test: this is used to find out the statistical significance of the individual regression coefficients. In this case, we use a two- tailed test to conduct it at a 5\% level of significance. When this is done the computed t-ratio ( $t$ cal) is compared with the theoretical t ( $t$-tab) with n-k degree of freedom.

4. F- test: this is a tool of the overall significance of the entire regression plane. It will be used to find out whether the joint impact of the explanatory variables actually have a significant influence on the dependent variable.

5. Durbin- Watson (test-to-test) the validity of the assumptions of non-auto-correlated disturbances Watson will be computed.

\section{Presentation of Empirical Results Summary of Stationary Unit Root Test}

Establishing stationarity is essential because if there is no stationarity, the processing of the data may produce biased result. The consequences are unreliable interpretation and conclusions. We test for stationarity using Adjusted DickeyFuller (ADF) tests on the data. The ADF tests are done on level series and first order differenced series.

Table 1: Summary of ADF test results

\begin{tabular}{|c|c|c|c|c|c|c|}
\hline Variables & $\begin{array}{c}\text { ADF } \\
\text { Statistics }\end{array}$ & $\begin{array}{c}\text { Lagged } \\
\text { Difference }\end{array}$ & $\begin{array}{c}\mathbf{1} \% \text { Critical } \\
\text { Value }\end{array}$ & $\mathbf{5 \%}$ Critical Value & $\begin{array}{c}\mathbf{1 0} \% \text { Critical } \\
\text { Value }\end{array}$ & $\begin{array}{c}\text { Order of } \\
\text { Integration }\end{array}$ \\
\hline GDP & 4.521405 & 1 & -3.592462 & -2.931404 & -2.603944 & $I(0)$ \\
\hline MS & -10.39023 & 1 & -3.600987 & -2.935001 & -2.605836 & $I(2)$ \\
\hline INF & -7.815622 & 1 & -3.621023 & -2.943427 & -2.610263 & $I(1)$ \\
\hline CRD & 5.771802 & 1 & -3.592462 & -2.931404 & -2.603944 & $I(0)$ \\
\hline INTC & -7.735941 & 1 & -3.596616 & -2.933158 & -2.604867 & $I(1)$ \\
\hline INFRA & 5.558257 & 1 & -3.592462 & -2.931404 & -2.603944 & $I(0)$ \\
\hline EXD & 3.761524 & 1 & -3.592462 & -2.931404 & -2.603944 & $I(0)$ \\
\hline PIND & -3.678491 & 1 & -3.600987 & -2.935001 & -2.605836 & $I(1)$ \\
\hline
\end{tabular}

Source: Researchers computation 
From table 1, above shows that four variables are stationary in its level difference, that is, $I(0)$ while three variables are stationary at their first differences, that is, $I(1)$ and only one of the variable is stationary at second difference, that is, $I(2)$. The table shows that gross domestic product, credit to the private sector, infrastructure and external debt are integrated at level difference while inflationary rate, interest rate on credit, price index are integrated at their first differences and money supply at second difference.

Since the ADF absolute value of each of these variables is greater than the $5 \%$ critical value, they are all stationary at their level, first and second differences as in table 1 above. The parameters are therefore stationary at the order of integration as indicated in the table 4.1 above. They are also significant at $1 \%, 5 \%$ and $10 \%$ respectively.

Since some of the variables are integrated at level form and some at first and second differences, we go further to carry out the cointegration test. The essence is to show that although all the variables are stationary, whether the variables have a long term relationship or equilibrium among them. That is, the variables are cointegrated and will not produce a spurious regression.

\section{Summary of Johansen Cointegration Test}

Cointegration means that there is a correlationship among the variables. Cointegration test is done on the residual of the model. Since the unit root test shows that the some variables are stationary at level difference, $I(0)$ while some at first and second difference $1(1)$ and $I(2)$ respectively, we therefore test for cointegration among these variables. The result is summarized in tables 2 below for Trace and Maximum Eigenvalue cointegration rank test respectively.

Table 2: Summary of Johansen Cointegration Test Result

Unrestricted Cointegration Rank Test (Trace)

\begin{tabular}{|c|c|c|c|c|}
\hline \multicolumn{5}{|c|}{ Unrestricted Cointegration Rank Test (Trace) } \\
\hline Hypothesized No. of CE(s) & Eigenvalue & Trace Statistic & 0.05 Critical Value & Prob.** \\
\hline None* & 0.991335 & 543.1388 & 159.5297 & 0.0000 \\
\hline At most $1 *$ & 0.975797 & 367.4474 & 125.6154 & 0.0000 \\
\hline At most $2 *$ & 0.940914 & 229.7607 & 95.75366 & 0.0000 \\
\hline At most $3^{*}$ & 0.826709 & 125.0968 & 69.81889 & 0.0000 \\
\hline At most $4^{*}$ & 0.501136 & 60.24374 & 9. 47.85613 & 0.0023 \\
\hline At most $5 *$ & 0.427421 & 34.51310 & 29.79707 & 0.0133 \\
\hline At most 6 & 0.246951 & 13.88172 & 15.49471 & 0.0862 \\
\hline At most 7 & 0.087490 & 3.387594 & 3.841466 & 0.0657 \\
\hline \multicolumn{5}{|c|}{ Trace test indicates 6 cointegrating eqn(s) at the 0.05 level } \\
\hline \multicolumn{5}{|c|}{$*$ denotes rejection of the hypothesis at the 0.05 level } \\
\hline$* * \mathrm{Ma}$ & cKinnon-Haug & Michelis (1999) & p-values & \\
\hline
\end{tabular}

\begin{tabular}{|c|c|c|c|c|}
\hline \multicolumn{5}{|c|}{ Unrestricted Cointegration Rank Test (Maximum Eigenvalue) } \\
\hline Hypothesized No. of CE(s) & Eigenvalue & Max-Eigen Statistic & $\mathbf{0 . 0 5}$ Critical Value & Prob.** \\
\hline None $^{*}$ & 0.991335 & 175.6913 & 52.36261 & 0.0000 \\
\hline At most 1 & 0.975797 & 137.6868 & 46.23142 & 0.0000 \\
\hline At most 2 & 0.940914 & 104.6639 & 40.07757 & 0.0000 \\
\hline At most 3 & 0.826709 & 64.85307 & 33.87687 & 0.0000 \\
\hline At most 4 & 0.501136 & 25.73064 & 27.58434 & 0.0847 \\
\hline At most 5 & 0.427421 & 20.63138 & 21.13162 & 0.0586 \\
\hline At most 6 & 0.246951 & 10.49413 & 14.26460 & 0.1815 \\
\hline At most 7 & 0.087490 & 3.387594 & 3.841466 & 0.0657 \\
\hline \multicolumn{5}{|c|}{ Max-eigenvalue test indicates 4 cointegrating eqn(s) at the 0.05 level } \\
\hline \multicolumn{5}{|c|}{ Source: Researchers computation rejection of the hypothesis at the 0.05 level } \\
\hline
\end{tabular}

Table 2 indicates that trace have only 6 cointegrating variables in the model while Maximum Eigenvalue indicated only 4 cointegrating variables. Both the trace statistics and Eigen value statistics reveal that there is a long run relationship among the variables. That is, the linear combination of these variables cancels out the stochastic trend in the series. This will prevent the generation of spurious regression results. Hence, the implication of this result is a long run relationship between economic growth and other monetary policy variables used in the model. 
Table 3: Summary of regression results

Dependent Variable: GDP

Method: Least Squares

Sample: 19802017

\begin{tabular}{|c|c|c|c|c|}
\hline Variable & Coefficient & Std. Error & t-Statistic & Prob. \\
\hline $\mathrm{C}$ & 21.83561 & 2.288837 & 0.095400 & 0.9246 \\
\hline MS & 1.150033 & 1.761196 & 7.652984 & 0.0000 \\
\hline INF & -18.14556 & 0.406272 & -0.441899 & 0.6614 \\
\hline CRD & 0.563556 & 1.609494 & 0.350145 & 0.7284 \\
\hline INTC & 14.61784 & 0.028115 & 3.778325 & 0.4418 \\
\hline INFRA & 4.167258 & 3.268603 & 5.274935 & 0.2110 \\
\hline EXD & 2.235045 & 1.103727 & 2.024998 & 0.0508 \\
\hline PIND & -35.94789 & 6.840258 & -0.525534 & 0.6026 \\
\hline R-squared & 0.969561 & \multicolumn{2}{|c|}{ F-statistic } & 154.7114 \\
\hline Adjusted R-squared & 0.963294 & \multicolumn{2}{|c|}{ Prob(F-statistic) } & 0.000000 \\
\hline S.E. of regression & 3841.928 & \multicolumn{2}{|c|}{ Durbin-Watson stat } & 2.273800 \\
\hline
\end{tabular}

Source: Researchers computation

\section{DISCUSSION OF FINDINGS}

To analyze the regression results as presented in table 3 , we employ economic a prior criteria, statistical criteria and econometric criteria.

\section{Discussion based on economic a priori criteria}

This subsection is concerned with evaluating the regression results based on a priori (i.e., theoretical) expectations. The sign and magnitude of each variable coefficient is evaluated against theoretical expectations.

From table 3, it is observed that the regression line have a positive intercept as presented by the constant (c) $=$ 21.83561. This means that if all the variables are held constant (zero), GDP will be valued at 21.83561. Thus, the apriori expectation is that the intercept could be positive or negative, so it conforms to the theoretical expectation.

From table 3, it is observed that money supply, credit to the private sector, interest rate on credit, infrastructure, external debt and price index has a positive relationship with economic growth. This means that when money supply, credit to the private sector, interest rate on credit, infrastructure, external debt and price index are increasing, these increase will bring about more growth in the economy of Nigeria. On the other hand, inflation was observed to have a negative sign. This means that if inflation is falling, there will be increase in growth of the economy.

From the regression analysis, it is observed that only interest rate on credit did not conform to the a priori expectation of the study as it was expected that interest rate on credit will be have a negative impact but reverse became the case.

From the analysis so far, it can be inferred that only interest rate on credit did not conform to the study a priori expectations while other variables of the study conform to the a priori expectation.

\section{Discussion based on statistical criteria}

This subsection applies the $\mathrm{R}^{2}$, adjusted $\mathrm{R}^{2}$, the S.E, the t-test and the f-test to determine the statistical reliability of the estimated parameters. These tests are performed as follows: From our regression result, the coefficient of determination $\left(\mathbf{R}^{2}\right)$ is given as 0.969561 , which shows that the explanatory power of the variables is very high and/or strong. This implies that $97 \%$ of the variations in the growth of the money supply, inflationary rate, credit to the private sector, interest rate on credit, infrastructure, external debt and price index are being accounted for or explained by the variations in economic growth. While other determinants of economic growth not captured in the model explain just 3\% of the variation in Nigeria economic growth.

The adjusted $\mathbf{R}^{2}$ supports the claim of the $\mathrm{R}^{2}$ with a value of 0.963294 indicating that $96 \%$ of the total variation in the dependent variable (economic growth is explained by the independent variables (the regressors)). Thus, this supports the statement that the explanatory power of the variables is very high and strong.

The standard errors as presented in table 4.3 show that all the explanatory variables were all low. The low values of the standard errors in the result show that some level of confidence can be placed on the estimates (see table 4.3 and also appendix 4).

The F-statistic: The F-test is applied to check the overall significance of the model. The F-statistic is instrumental in verifying the overall significance of an estimated model. The F-statistic of our estimated model is 154.7114 and the probability of the F-statistic is 0.000000 (see table 3). Since the probability of the F-statistic is less than 0.05 , we conclude that the explanatory variables have significant impacts on economic growth in Nigeria.

\section{Summary of Findings}

The study attempted to examine the impact of monetary policy on economic growth of Nigeria using secondary time series data collected from Central Bank of Nigeria (CBN) statistical bulletin from 1980-2017. The study adopted the ordinary least square (OLS) in executing its analysis after determining stationarity of our variables using the ADF Statistic, as well as the cointegration of variables using the Johansen approach and was discovered that some variables which was integrated at level difference was stationary while other variables that was integrated at their first and second differences are also stationary at the order of integration. Also, the findings show that there is a long term relationship among the variables in the model.

From the empirical reviewed work, some authors argued that monetary policy is negatively related to economic growth; while some authors argued that it is positively 
related. Others have a reversed view about the result. However, from empirical analysis of this study, it was found that monetary policy is positively related to economic growth in Nigeria.

Again, from our analysis so far, this study discovered that the F-statistic conducted was found that there is significant impact between the dependent and independent variables in the model. It is also observed that one of the variables did not conform to the theoretical or a priori expectation of the study.

Whereas money supply, inflation, credit to the private sector, infrastructure, external debt and price index conform to the study theoretical postulation, interest rate on credit did not conform to the study a priori expectation.

Furthermore, while money supply, credit to the private sector, interest rate on credit, infrastructure, external debt and price index have a positive impact on economic growth, inflation has a negative impact on economic growth but conforms to the a priori expectation.

The study also found out that it is only money supply, interest rate on credit, infrastructure and external debt were statistically significant in explaining its impacts on economic growth while other variables used in the study were all found to be statistically insignificant in explaining the growth rate of the Nigerian economy.

Finally, both $\mathrm{R}^{2}$ and adjusted $\mathrm{R}^{2}$ show that the explanatory power of the variables is very high and strong in explaining the variations of the economic growth by the variables of the model. Also, the standard errors show that all the explanatory variables were all low. The low values of the standard errors in the result show that some level of confidence can be placed on the estimates.

Monetary policy plays a significant role in the well-being of an economy through its stabilizing role. This paper focuses on investigating the effects of monetary policy on economic growth. Findings of the study show that in Nigeria, adjusting the monetary policy through the money supply, inflation and credit control has an insignificant impact on economic growth. Although they indicate a positive impact on GDP, only inflation is significant.

The role of the Central bank in regulating the liquidity of the economy which affects some macroeconomic variables such as the output, employment and prices cannot be overemphasized. This study applied ordinary least square (OLS) to determine the impact of monetary policy on the Nigeria's economic growth for the period 1980-2017. This study concludes therefore that the inability of monetary policies to effectively maximize its policy objective most times is as a result of the shortcomings of the management inefficiency and policy instruments used in Nigeria as such limits its contribution to growth.

\section{RECOMMENDATIONS}

Based on the findings made in the course of this study, the following recommendations are hereby suggested below:

1. The Central Bank of Nigeria should be granted full autonomy on its monetary policy functions. Partial autonomy should be replaced with full autonomy for the central banks in the developing economies at large which is invariably subjected to government interference and its politics.

2. Government should be spending on the productive sectors of the economy so as to promote economic growth, encouraging foreign direct investment (FDI) to boost domestic investments among others.

3. Monetary policies should be used to create a favourable investment climate that attracts both domestic and foreign investments thereby promoting a sustainable economic growth.

4. Central bank of Nigeria should eliminate the price uncertainties associated with inflation which can contribute to a nation's economic health.

5. For monetary policy to have a desired impact on the real economy and inflation, which is the fundamental objective of monetary policy, it is essential that changes in the short-term market and interest rate should ultimately transform into changes in other interest rates in the economy (that is, interest rate changes are passed through to retail interest rates for loans and deposits), which then influence the overall level of economic activity and prices.

\section{REFERENCES}

[1] Ahmad, D. Afzal, M. \& Ghani, U. (2016). Impact of monetary policy on economic growth empirical evidence of Pakistan. International Journal of Applied Economic Studies, 4(6), 1-10.

[2] Adigwe, P. K., Echekoba, F.N. \& Onyeagba, J. B.C. (2015). Monetary policy and economic growth in Nigeria: A critical evaluation. IOSR Journal of Business and Management, 17(2), 110-119.

[3] Anowor, O. F., \& Okorie, G. C. (2016). A reassessment of the impact of monetary policy on economic growth: Study of Nigeria. Retrieved from http://www.eajournals.org /wp-content/uploads/AReassessment-of-the Impact-of-Monetary-Policy-onEconomic-GrowthStudyof- Nigeria.pdf

[4] Anazor K. 0. (2015). Effect of monetary policy on economic growth and development in Nigeria (19702013). Unpublished Thesis. Nnamdi Azikiwe University, Awka.

[5] Ayodeji, A. \& Oluwole, A. (2018) Impact of monetary policy on economic growth in Nigeria. Open Access Library Journal, 5(e4320), 1-13.

[6] CBN (1992). Monetary policy department: http://www.cenbank.org. Central Bank of Nigeria Statistical Bulletin for several issues: http://www.cenbank.org/

[7] Fasanya, I .0., Onakoya, A.B.O. \& Agboluaje, M. A. (2013). Does monetary policy influence economic growth in Nigeria? Asian Economic and Financial Review, 2013, 3(5), 635-646.

[8] Ajayi, I., (1999). Evolution and functions of central banks. Central Bank of Nigeria Economic and Financial Review, 37(4): 11-27.

[9] Charles, A. N. B. (2012). Investigating the performance of monetary policy on macroeconomic instability in Nigeria: A Rational Expectation Approach. Journal of Social Sciences, 12(2): 93-100. Manufacturing Sector in Nigeria. Arabian Journal of Business and Management Review, 2(1),12-25. 
International Journal of Trend in Scientific Research and Development (IJTSRD) @ www.ijtsrd.com eISSN: 2456-6470

[10] Chukwu, A.C (2009). Measuring the effects of monetary policy innovations in Nigeria. A Structural Vector Autoregressive Approach. African Journal of Accounting, Economic Finance \& Banking Research, 15(5).

[11] Nasko, A. M. (2016). Impact of monetary policy on the economy of Nigeria. Pyrex Journal of Business and Finance Management Research, 2 (10), 163-179.

[12] Nwoko, N. M., Ihemeje, J. C. \& Anumadu, E. (2016). The impact of monetary policy on the economic growth of Nigeria. An International Multi-disciplinary Journal, Ethiopia, 10(3), 192-206.

[13] Okafor, P. N. (2009). "Monetary policy framework in Nigeria: Issues and challenges," CBN, Economic and Financial Review, 33(2), (2009).

[14] Onyeiwu, C. (2012). Monetary Policy and Economic Growth of Nigeria. Journal of Economics and Sustainable Development, 3(7), 62-70.
[15] Onyeiwu, C., (2012). Monetary policy and economic growth of Nigeria. Journal of Economics and Sustainable Development, 3(7): 62 -70.

[16] Precious, C. (2014). Impact of monetary policy on economic growth: A case study of South Africa. Mediterranean Journal of Social Sciences. https:/ /doi.org/10.5901/mjss.2014.v5n15p76

[17] Srithilat, K. \& Sun, G. (2017). The Impact of Monetary Policy on Economic Development: Evidence from Lao PDR. Global Journal of Human-Social Science: E Economics, 17(2), 8-16.

[18] Uchendu, 0. A., "Monetary policy in Nigeria," $C B N$ Economic and Financial Review, 33(2), (2009): 11-18.

[19] Ufoeze, L.O., Odimgbe, S. O., Ezeabalisi, V. N. Alajekwu, U. B. (2018). Effect of monetary policy on economic growth in Nigeria: An empirical investigation. Annals of Spiru Haret University, Issue 1. 